Ann. Biol. anim. Bioch. Biophys., 1979, 19 (2 A), 429-437.

\title{
Selective protein incorporation by vitellogenic Salmo gairdneri oocytes in vitro
}

\author{
par C. M. CAMPBELL *, B. JALABERT **
}

with technical assistance of Gill CAMPBELL, Micheline HEYDORFF

Laboratoire de Physiologie des Poissons, I.N.R.A. 78350 Jouy en Josas, France.

Summary. An in vitro method is presented for investigation of protein incorporation into the ovarian follicles of rainbow frout (Salmo gairdneri).

A protein induced into serum of $S$. gairdneri, after estrogen treatment, was incorporated into vitellogenic follicles to a greater extent than other serum proteins of $S$. gairdneri or bovine serum albumin (BSA) which served as controls. A large proportion of the incorporated BSA and other non-vitellogenic proteins is probably associated with follicular tissues other than the oocyte.

These results offer further evidence that the estradiol-induced serum protein found in teleosts is vitellogenin, the precursor of oocyte yolk proteins.

\section{Introduction.}

In the model proposed for vitellogenesis of amphibia and birds, a yolk protein precursor, vitellogenin, is synthesised by the liver, transported by the blood, and incorporated into vitellogenic oocytes (Follett, Nicholls and Redshaw, 1968 ; Wallace and Dumont, 1968 and Bergink et al., 1974).

Support for a similar model for vitellogenesis in teleosts is now accumulating. Numerous workers have demonstrated changes in serum constituents associated with vitellogenesis in female teleosts and Utter and Ridgeway (1967), Plack ef al. (1971) and Amirante (1972) characterized a serum protein in Parophyrys vetulus, Hippoglossus stenolepis, Gadus morhua and Salmo gairdneri as a probable yolk precursor by its crossreactivity with antibodies to gonadal extracts. Plack and Frazer (1971), Emmersen and Peterson (1976) and Campbell and Idler (1976) presented data to indicate that vitellogenin is synthesised in the teleost liver and Campbell and Idler (1976), Campbell (1978) $\mathrm{Ng}$ and Idler (1978) found that incorporation of the precursor inio vitellogenic ovaries is stimulated by teleost pituitary gonadotropins which exhibit no affinity to concanavalin $\mathrm{A}$.

Wallace ef al. $(1970,1976)$ have studied the amphibian mechanisms of protein

* Present address : Marine Sciences Research Laboratory, Memorial University of Newfoundland, St. John's Nfld. A1C 557, Canada.

* Present adress : Laboratoire de Physiologie des Poissons, I. N. R. A., campus de Beaulieu, 35042 RENNES Cédex, France. 
incorporation into oocytes using a system of in vitro incubation of oocytes from Xenopus laevis. This system was adopted to study the incorporation of protein into oocytes of Salmo gairdneri and investigate the selectivity of protein incorporation.

\section{Materials and methods.}

Donor fish and preparation of oocytes.

Hatchery reared S. gairdneri were maintained in a recirculated water raceway system. Follicles ( $>3 \mathrm{~mm}$ in diameter) were obtained from the ovaries of females undergoing active vitellogenesis between September and early December.

Incorporation assays were carried out on different systems :

1. Individual follicles separated from ovaries using small forceps : Follicles were isolated and incubated in trout balanced salts solution (TBSS) buffered at $\mathrm{pH} 8.0$ by HEPES-NaOH (Jalabert, 1976) : $\mathrm{NaCl} 133 \mathrm{mM} ; \mathrm{KCl} 3.1 \mathrm{mM} ; \mathrm{MgSO}_{4} 0.3 \mathrm{mM}$; $\mathrm{MgCl}_{2} 1.0 \mathrm{mM} ; \mathrm{CaCl}_{2} 3.4 \mathrm{mM}$; glucose $5.6 \mathrm{mM}$; HEPES-NaOH $40 \mathrm{mM}$, penicilin $100000 \mathrm{U} / \mathrm{l}$; streptomicin sulphate $100000 \mu \mathrm{g} / \mathrm{l}$.

2. Individual follicles isolated by mild collagenase treatment using BSA to neutralize non-specific proteolytic effects. Small chunks of ovary were actively agitated $\left(1.7 \mathrm{~Hz}\right.$ ) for $1-2 \mathrm{~h}$ at $15^{\circ} \mathrm{C}$ in TBSS containing $2 \mathrm{mg} \mathrm{ml}^{-1}$ collagenase (Sigma, type II) and $5 \mathrm{mg} \mathrm{ml}^{-1}$ BSA, resulting in rupture of the basement membrane between thecal layers and ovarian tissue.

3. Individual oocytes surrounded only by granulosa cells : Following stage 2, follicles were agitated very gently $\left(<0.5 \mathrm{HZ}\right.$ in $2 \mathrm{mg} \mathrm{ml}^{-1}$ collagenase, $15 \mathrm{mg} \mathrm{ml}^{-1}$ BSA), for a further $2 \mathrm{hrs}$. This treatment resulted in the rupture of the basement membrane between granulosa and thecal layers.

4. Individual naked oocytes: When follicles prepared to stage 3 were aspirated several times into a closely fitting pipette the granulosa layer was usually scraped off. Occasionally exposure for $10 \mathrm{~min}$ to $\mathrm{Ca}, \mathrm{Mg}$-free TBSS $+5 \mathrm{mMEDTA}$ was required before mechanical treatment.

Follicles were sorted using a dissecting microscope in order to begin incubation within 5-10 hrs of the death of the donor fish. Those selected retained the appearance of follicles from a freshly killed fish.

Individual follicles were placed in the wells of Cooke microtiter plates and excess medium was aspirated and replaced with $50 \mu \mathrm{l}$ of experimental incubation medium. Experimental lots of 12 or 24 individual oocytes from each fish were incubated for 18-25 hrs at 12.5 or $15^{\circ}$ under an $\mathrm{O}_{2} / \mathrm{N}_{2}$ atmosphere (50:50) saturated with water to prevent problems of evaporation of medium.

At the end of incubation the wells were rinsed three times with saline to wash any unabsorbed proteins from the follicles. The oocyie was then examined using a dissecting microscope and the diameters of those having retained a similar appearance as at the beginning of incubation were recorded. These oocytes were dissolved in Solvene (Packard Instruments) and radioactivity counted. Disintegrations per minute and per $\mathrm{mm}^{2}$ of oocyte surface were calculated and the mass of protein incorporated calculated using the specific activity of the labelled protein determined using Lowry protein quantification. 
Protein labelling.

Ten $\mathrm{mg}$ of test protein in $0.2-1.0 \mathrm{ml}$ of $0.5 \mathrm{M} \mathrm{NaCl}, 0.02 \mathrm{M} \mathrm{CaCl}_{2}$ was adjusted to $\mathrm{pH} 9.0$ with $\mathrm{NaOH}$ at $0{ }^{\circ} \mathrm{C} .100 \mu \mathrm{Ci}$ of ${ }^{14} \mathrm{C}$-formaldehyde (CEA France $-30 \mathrm{mCi} \mathrm{mM}^{-1}$ ) was added and the solution mixed. Sodium borohydride $(20 \mu \mathrm{l}: 100 \mu \mathrm{g})$ was added four times at 30 second intervals, followed by a final $100 \mu \mathrm{l}(500 \mu \mathrm{g})$, with mixing each time. After $16 \mathrm{hrs}$ at $0^{\circ} \mathrm{C}$ the labelled protein mixture was freed from reaction products using Sephadex G-25 equilibrated with TBSS (without glucose and antibiotics). Labelled proteins were stored at $-70^{\circ}$ at concentrations of $5-10 \mathrm{mg} / \mathrm{ml}$. This method, based on Rice

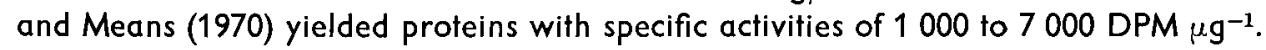

Protein incorporation experiments.

The proteins described in table 1 and figure 1 were labelled by reductive methylation. The incorporation of preparations which were essentially free of the estrogeninduced serum protein was compared with incorporation of vitellogenic proteins.

TABLE I

Description of test proteins

\begin{tabular}{|c|c|c|}
\hline Symbol & Source & Isolation \\
\hline \multicolumn{3}{|l|}{ Control } \\
\hline $\begin{array}{l}\text { BSA } \\
C_{1} \\
C_{2}\end{array}$ & $\begin{array}{l}\text { Bovine Serum Albumin } \\
\text { Serum from } \delta \text { S. gairdneri }\end{array}$ & $\begin{array}{l}\text { Sigma ; Fraction V } \\
\text { Untreated } \\
\text { Principle peak in TEAE chro- } \\
\text { matography }\end{array}$ \\
\hline $\mathrm{C}_{3}$ & $\begin{array}{l}\text { Serum from estrogen-treated } q \mathrm{~S} . \\
\text { gairdneri }\end{array}$ & - \\
\hline $\mathrm{C}_{4}$ & $\begin{array}{l}\text { Serum from non-vitellogenic } q S \text {. } \\
\text { goirdneri }\end{array}$ & $\begin{array}{l}\text { Second peak area in TEAE } \\
\text { chromatography }\end{array}$ \\
\hline \multicolumn{3}{|l|}{ Vitellogenic } \\
\hline$v_{1}$ & $\begin{array}{l}\text { Serum from estrogen-treated } \hat{\alpha} \mathrm{S} \text {. } \\
\text { gairdneri }\end{array}$ & Untreated \\
\hline$v_{2}$ & प्रकाता & $\begin{array}{l}\text { Second peak in TEAE chromato- } \\
\text { graphy }\end{array}$ \\
\hline$v_{3}$ & - & - \\
\hline
\end{tabular}

The effect of varying concentration of these proteins on incorporation into oocytes in the presence and absence of $2 \mathrm{mg} \mathrm{ml}^{-1}$ BSA was tested. The effect of varying BSA concentration on incorporation of ${ }^{14} \mathrm{C}$-labelled $V_{1}, V_{2}, C_{1}$ and $B S A$ was evaluated.

The incorporation of ${ }^{14} \mathrm{C}$-vitellogenin and ${ }^{14} \mathrm{C}$-BSA by follicles which were prepared enzymatically or mechanically was tested in order to characterize any interference by other ovarian tissues.

\section{Results.}

Preliminary trials showed that addition of BSA to the collagenase solution resulted in preparation of follicles which retained the morphological characteristics of those excised from ovaries of freshly killed animals. Without BSA few collagenase treated 

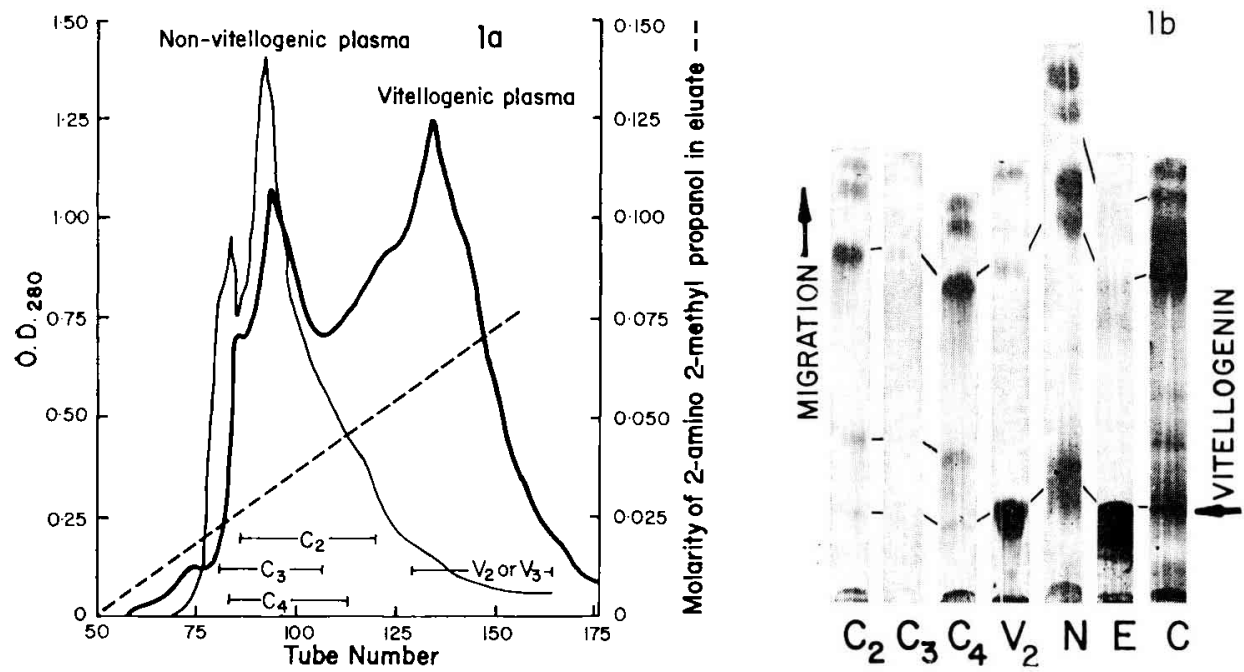

FIG. 1. - (a) Typical profiles of serum proteins eluted from a $2.6 \mathrm{~cm} \times 40 \mathrm{~cm}$ column of TEAE cellulose by o linear gradient of $0.015 \mathrm{M} 2$ amino-2 methyl-1 propanol ; $0.0025 \mathrm{M}$ citric acid to $0.125 \mathrm{M} 2$ amino-2 methyl-1 propanol ; $0.04 \mathrm{M}$ citric acid. Bars show elution positions of partially purified test fractions.

(b) Polyacrylamide gels (6 p. 100 Tris-glycine system) showing estrogen induced profein $(V)$ and comparison of protein mixtures tesfed. $\mathrm{C}$ : serum from a previtellogenic adult $P$; $\mathrm{E}$ : serum from estradioltreated $q ; \mathrm{N}$ : serum from a normal vitellogenic ?.

oocytes were viable after incubation. Seventy-five percent of follicles separated enzymatically retained these characteristics till the end of the incubation period but only 45 p. 100 of those isolated manually were similar.

\section{TABLE 2}

$\mathrm{ng} \mathrm{mm}^{-2}$ of ${ }^{14} \mathrm{C}$-labelled protein in follicles or oocytes after $21 \mathrm{hrs}$ incubation with $1 \mathrm{mg} \mathrm{m}^{-1}$ fest protein, $2 \mathrm{mg} \mathrm{m}^{-1}$ BSA (fish 1) or $2 \mathrm{mg} \mathrm{ml}^{-1}$ fest protein only (fish 2) Mean $\pm S E$; numbers in parenthesis indicate number of viable oocytes remaining ( $a, b, c$ indicate $P \leqslant 0.001$ for comparaison by t-test).

Groups 2, 3 and 4 were all prepared by collagenase treatment

\begin{tabular}{|c|c|c|c|}
\hline \multirow{3}{*}{$\begin{array}{c}\text { Treatment of oocyle before } \\
\text { incubation }\end{array}$} & \multicolumn{3}{|c|}{ Test protein } \\
\hline & \multicolumn{2}{|c|}{${ }^{14} \mathrm{C}$-vitellogenin $\left(\mathrm{V}_{2}\right)$} & \multirow{2}{*}{$\begin{array}{l}{ }^{14} \text { C-BSA } \\
\text { Fish } 2\end{array}$} \\
\hline & Fish 1 & Fish 2 & \\
\hline $\begin{array}{l}\text { 1. Manual separation } \ldots \ldots \ldots \\
\text { 2. Collagenase separation.... } \\
\text { 3. Theca removed ......... } \\
\text { 4. Granulosa removed } \ldots \ldots\end{array}$ & $\begin{array}{l}40 \pm 1(22)^{a} \\
67 \pm 6(22)^{a} \\
92 \pm 6(24) \\
61 \pm 4(19)\end{array}$ & $\begin{array}{l}59 \pm 3(14)^{b} \\
78 \pm 3(18)^{b} \\
68 \pm 3(9) \\
43 \pm 2(13)\end{array}$ & $\begin{array}{l}20 \pm 1(13)^{c} \\
13 \pm 1(21)^{c} \\
17 \pm 2(10) \\
-\quad\end{array}$ \\
\hline
\end{tabular}

Significantly $(P<0.001)$ greater quantities of ${ }^{14} \mathrm{C}$-vitellogenin $\left(V_{2}, V_{3}\right)$ were found associated with oocytes which had been prepared by collagenase dissociation (table 2 ) and conversely the quantity of ${ }^{14} \mathrm{C}-\mathrm{BSA}$ was greatest $(P<0.001)$ in manually dissociated oocytes though there was always less BSA than vitellogenin incorporation. In a 


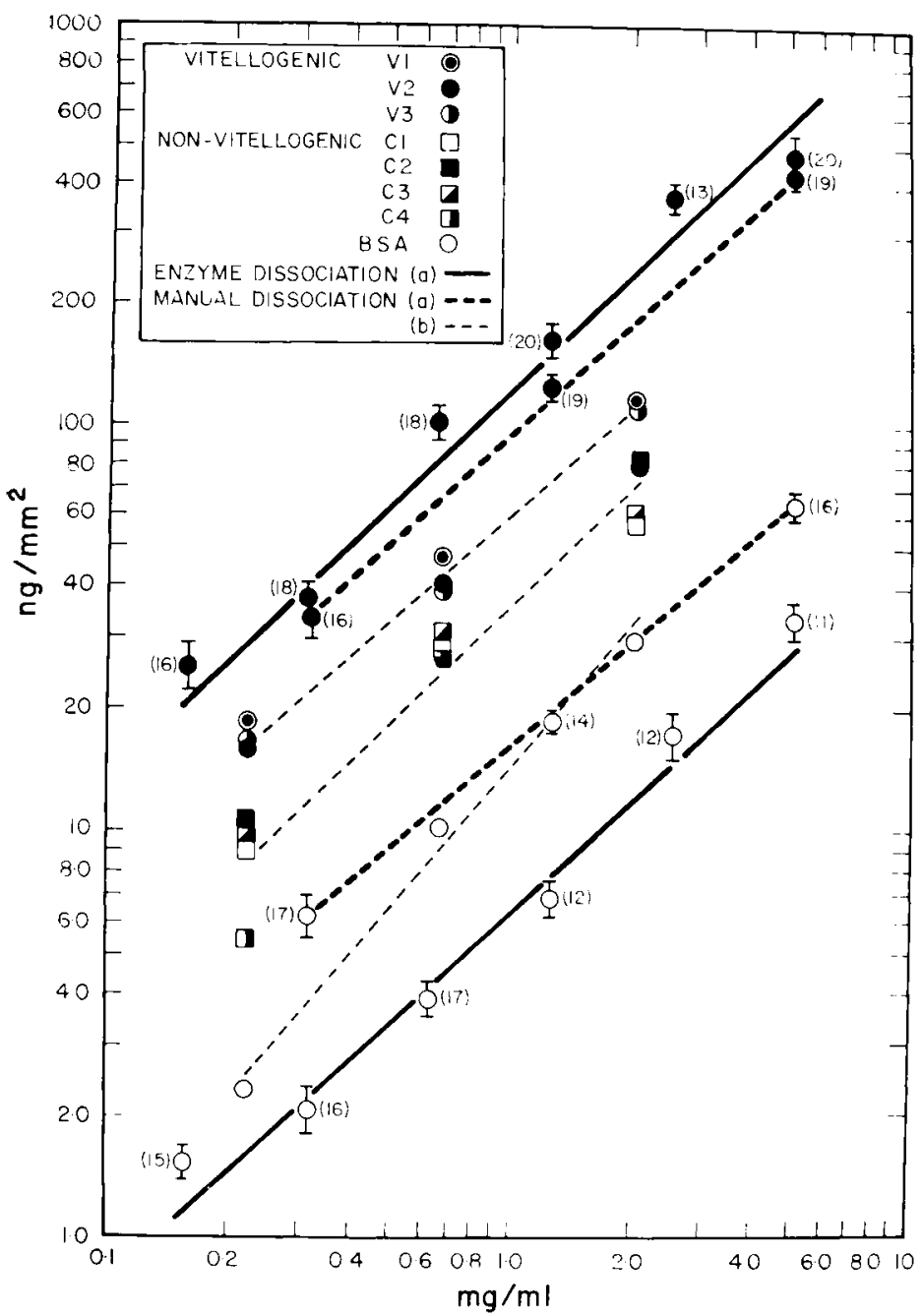

FIG. 2. - (a) Comparison of protein $\left({ }^{14} \mathrm{C}-\mathrm{V}_{2},{ }^{14} \mathrm{C}-\mathrm{BSA}\right)$ incorporation into oocyfes dissociated manually or by collogenase incubated with various concentrations of ${ }^{14} \mathrm{C}-\mathrm{V}_{2}$ in the absence of unlabelled BSA.

(b) Comparison of incorporation of ${ }^{14} \mathrm{C}$-labelled-vitellogenic and non-vitellogenic proteins and ${ }^{14} \mathrm{C}-\mathrm{BSA}$ at different concentrations in the presence of $2 \mathrm{mg} \mathrm{ml}^{-1}$ BSA into manually dissociated oocytes.

Data points represent mean incorporation \pm standard error for $(n)$ viable oocytes after $20 \mathrm{hrs}$. Lines are least squares fit.

further experiment (fig. 2) it was found that these phenomena were reproduced similarly at different concentrations for vitellogenic and non-vitellogenic proteins.

In each of the above cases less ${ }^{14} \mathrm{C}$-labelled BSA or control proteins than vitellogenic.protein was found incorporated into oocytes. Analysis of variance shows that vitellogenic proteins $\left(V_{1}, V_{2}, V_{3}\right)$ were incorporated significantly $(P<0.001)$ more actively than all non-vitellogenic test proteins into manually separated follicles (table 3). At different protein concentrations the same tendency was found (fig. 2). 
TABLE 3

$\mathrm{ng} \mathrm{mm^{-2 }}$ of ${ }^{14} \mathrm{C}$-labelled protein in manually separated follicles after incubotion with $2 \mathrm{mg} \mathrm{m}^{-1}$ test protein in the presence of $2 \mathrm{mg} \mathrm{ml}-1$ BSA.

Mean \pm SE for (n) surviving oocytes from the initial 12 (fish 1) or 24 (fish 2) placed in culture ( $a:$ no significant difference $; b: P \leqslant 0.001$ ).

\begin{tabular}{|c|c|c|c|c|c|c|c|}
\hline \multicolumn{8}{|c|}{ Test protein } \\
\hline & $V_{1}$ & $v_{2}$ & $V_{3}$ & $C_{1}$ & $C_{2}$ & $\mathrm{C}_{3}$ & $C_{4}$ \\
\hline $\begin{array}{l}\text { Fish } 1^{a} \ldots \\
\text { Fish } 2^{a} \ldots\end{array}$ & $\begin{array}{c}62 \pm 3 \\
(4) \\
116 \pm 8 \\
(12)\end{array}$ & $\begin{array}{c}78 \pm 2 \\
(4) \\
110 \pm 7 \\
(20) \\
b\end{array}$ & $\begin{array}{c}80 \pm 12 \\
(4) \\
107 \pm 7 \\
(20)\end{array}$ & $\begin{array}{c}35 \pm 2 \\
(5) \\
56 \pm 3 \\
(21)\end{array}$ & $\begin{array}{c}37 \pm 1 \\
(4) \\
44 \pm 2 \\
(23)\end{array}$ & $\begin{array}{c}42.6 \pm 4 \\
(4) \\
55 \frac{1}{(19)} \\
b\end{array}$ & $\begin{array}{c}30 \pm 1 \\
(5) \\
47 \underset{(20)}{ \pm} 2.6\end{array}$ \\
\hline
\end{tabular}

A single experiment showed that increasing BSA concentrations up to $9 \mathrm{mg} / \mathrm{ml}^{-1}$ did not affect the incorporation of vitellogenic $\left(V_{1}, V_{3}\right)$ or non-vitellogenic $\left(C_{1}\right)$ ${ }^{14} \mathrm{C}$-labelled proteins but higher concentrations may inhibit incorporation of nonvitellogenic serum proteins (fig. 3). However the incorporation of ${ }^{14} \mathrm{C}$ BSA decreased as a function of dilution of ${ }^{14} \mathrm{C}$ labelled BSA by non-labelled protein. Incubation performed in the presence of $27 \mathrm{mg} \mathrm{ml}$-1 BSA (normal plasma protein concentrations Ca $50 \mathrm{mg} \mathrm{ml}^{-1}$ ) showed a marked reduction of incorporation of male serum protein $\left(\mathrm{C}_{1}\right)$ also.

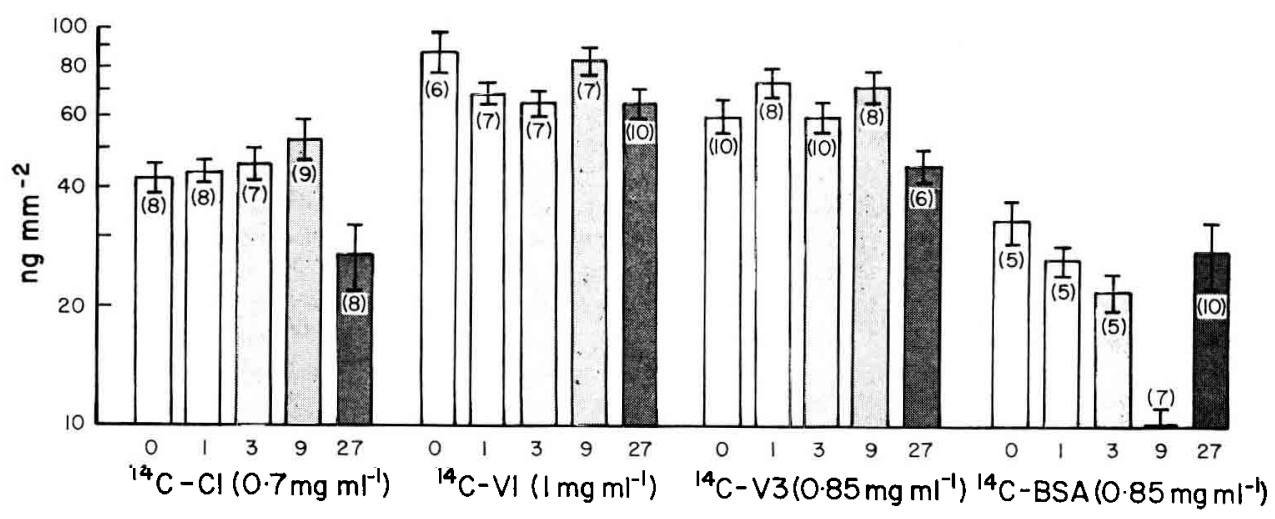

FIG. 3. - Incorporation of labelled proteins by manually separated oocyles during incubation with 1, 3, 9 or $27 \mathrm{mg} \mathrm{m}^{-1}$ of unlabelled BSA (mean and standard error for $(\mathrm{N})$ viable oocytes after $19 \mathrm{hrs}$ ).

Two attempts to incubate oocytes from which thecal or all follicular tissues had been removed yielded conflicting data, perhaps due to the extensive mortality of oocytes from one fish (table 2). Removal of thecal tissues may facilitate incorporation but it is probable that the totally naked oocytes are too fragile for the results to be conclusive. 


\section{Discussion.}

Immunological studies have demonstrated cross reactivity of the protein, induced into the serum of estradiol treated fish, or present in vitellogenic females, with antibodies to the yolk protein (Utter and Ridgeway (1967), Plack ef al. (1971). In the present study, it was found that the incorporation of this type of estradiol-induced protein into vitellogenic oocytes was always much greater than for BSA (fig. 2, fig. 3, tables 2 and 3) and the «non-vitellogenic » proteins (isolated from male serum, non-vitellogenic and vitellogenic female serum) were generally associated with follicles in a similar manner to BSA. These data support the hypothesis that this estrogen-induced serum protein is vitellogenin, the yolk precursor.

Wallace and Jared (1976) showed that protein incorporation by the vitellogenic oocytes of Xenopus Laevis is highly specific for Xenopus vitellogenin which was accumulated in greater quantities than other (non-amphibian and non-vitellogenic) test proteins. In the present work no absolute specificity has been shown but it is clear that BSA was unable to inhibit the incorporation of vitellogenic protein (fig. 3). If does however competitively inhibit the incorporation of ${ }^{14} \mathrm{C}-\mathrm{BSA}$ (fig. 3) as evidenced by lower levels of tracer incorporation in the presence of higher concentrations of unlabelled BSA. The effect of competition of unlabelled BSA with ${ }^{14} \mathrm{C}$-BSA (fig. 2) results in a different response (greater slope) to increasing the concentration of ${ }^{14} \mathrm{C}$-labelled protein, whereas the incorporation responses to changes in concentration were similar for all proteins including ${ }^{14} \mathrm{C}$-BSA in the absence of competing unlabelled BSA. This suggests that the association of each protein with incubated follicles is to some degree site specific.

Wallace and Jared (1976) found that there was no appreciable competition between BSA and ${ }^{14} \mathrm{C}$-vitellogenin for partially denuded oocytes of $X$. laevis and they felt justified in applying the concept of enzyme kinetics to describe the incorporation of proteins. We have not attempted to make similar interpretations since we used entire follicles with the attendent problems of non-specific association of protein to thecal tissues.

It is probable that a part of the ${ }^{14} \mathrm{C}$-labelled protein represents incorporation into or association with follicular tissues rather than incorporation into oocytes. Mechanically isolated oocytes are surrounded by granulosa and thecal layers and also interstitial tissues whereas when oocytes are separated enzymatically they are only invested by granulosa and thecal layers. The vitellogenin «incorporation » is higher for enzymatically treated oocytes suggesting that the basement membrane between interstitial tissues and thecal layers may act as a barrier to uptake of vitellogenin. Wallace ef al. $(1970,1973)$ found that oocytes from $X$. laevis must be divested of epithelial and thecal layers prior to incubation in order to facilitate incorporation of vitellogenin. The lower ${ }^{14} \mathrm{C}-\mathrm{BSA}$ incorporation by follicles incubated without interstitial tissues (after enzyme dissociation) compared to entire follicles (manual dissociation) suggests that there may be extensive association of non-vitellogenic proteins with these tissues which are not removed by washing after incubation before counting (table 2, fig. 2). In fact, Campbell (1978) showed by removal of follicular tissues after incubation that, whereas only 15 p. 100 of total incorporated follicular vitellogenin was found in 
follicle cells and 85 p. 100 in the oocyte, 60 p. 100 of incorporated non-vitellogenic trout serum protein was associated with the follicles cells and only 40 p. 100 in the oocyte. Thus it is probable that the specificity of true incorporation into the oocytes is greater than is suggested by results presented here.

The methods of oocyte preparation and incubation have proven equally satisfactory for oocytes $(0.75-1.5 \mathrm{~mm}$ diam) from trout which had not begun active vitellogenesis (Campbell, 1978). The addition of BSA to the incubation medium is apparently unnecessary though addition during collagenase treatment is the key to successful use of this technique.

Labelling of the proteins by reductive methylation seems not to extensively damage the proteins. Wallace and Jared (1976) found that chemically labelled vitellogenin was incorporated by oocytes of $X$. laevis with similar kinetics to vitellogenin labelled by incorporation of labelled amino acid in vivo. Busby ef al. (1977) showed that biological activities and half-lives were unchanged when three enzymes were labelled by this in vitro method.

This approach to the study of vitellogenesis lends itself to investigations of the activity of vitellogenic gonadotropins (Campbell, 1978) and may enable evaluation of the mode of action of these gonadotropins as well as exploration of the mechanisms of yolk incorporation by studies similar to those of Wallace et al. (1970-1976) made in amphibia.

Reçu en aoaf 1978.

Accepté en octobre 1978.

Acknowledgments. - I thank The Royal Society for their support in the form of a European Fellowship, during this work. This work was partly supported by « Le Ministère de l'Environnement et de la Culture », grant no. 76-37.

Résumé. Une méthode d'étude de l'incorporation de protéines in vitro dans le follicule ovarien de la truite arc-en-ciel (Salmo gairdneri) est décriłe.

Une protéine sérique donf l'apparition est induite par traitement œstrogénique in vivo, s'est révélée être mieux incorporée in vifro dans les follicules en vitellogenèse que les autres protéines sériques ou la BSA qui servent de témoins. Une proportion importante de celles-cí est d'ailleurs probablement associée aux tissus folliculaires, plutôt qu'aux ovocytes euxmêmes.

Ces résultats contribuent à démontrer que la protéine sérique induite par traitement œstrogénique chez les téléostéens est bien la vitellogénine, précurseur de protéines vitellines: de l'ovocyte.

\section{References}

AMIRANTE G. A., 1972. Immunochemical studies on rainbow trout (Salmo gairdneri Rich) lipovitellin. Acta embryol. experiment., Suppl., 373-383.

BERGINK E. W., WALLACE R. A., VAN DE BERG J. A., BOS E. S., GRUBER M., BEERT A. B., 1974. Estrogen induced synthesis of yolk proteins in roosters. Am. Zool., 14, 1177-1193.

BUSBY T. F., YU S. D., GAN J. C., 1977. Radioactive labelling of $\alpha$-antitrypsin, trypsin and chymotrypsin by reductive methylation : Properties of the labelled derivatives. Arch. Biochem. Biophys., 184, 267-275. 
CAMPBELL C. M., 1978. In vitro stimulation of vitellogenin incorporation into trout oocytes by salmon pituitary extracts. Ann. Biol. anim. Biochim. Biophys., 18, 1013-1018.

CAMPBELL C. M., IDLER D. R., 1976. Hormonal control of vitellogenesis in hypophysectomized winter flounder (Pseudopleuronectes americanus Walbaum). Gen. comp. Endocrinol., 28, 143-150.

EMMERSEN B. K., PETERSON J., 1976. Natural occurrence, and experimental induction by estradiol$17 \alpha$ of a lipophosphoprotein (vitellogenin) in flounder (Platichthys flesus L.). Comp. Biochem. Physiol., 54B, 443-446.

FOLLETT B. K., NICHOLLS T. J., REDSHAW M. R., 1968. The vitellogenic response in the South African clawed toad (Xenopus laevia Daudin). J. Cell Physiol., 72, suppl., 91-102.

JALABERT B., 1976. In vitro oocyte maturation and ovulation in rainbow trout (Solmo gairdneri), Northern Pike Esox lucius, and Goldfish (Carassius auratus). J. Fish. Res. Bd. Canada, 33, 974-988.

NG BUN T., IDLER D. R., 1978. Big and little forms of plaice vitellogenic and maturational hormones. Gen. comp. Endocrinol., 34, 408-420.

PLACK P. A., FRAZER N. W., 1971. Incorporation of L- $\left({ }^{14} \mathrm{C}\right)$ leucine into egg proteins by liver slices from cod. Biochem. J., 121, 857-862.

PLACK P. A., PRITCHARD D. J., FRAZER N.W., 1971. Egg protein in cod serum. Natural occurrence and induction by injection of oestradiol 3-benzoate. Biochem. J., 121, 847-856.

RICE R. H., MEANS G. E., 1970. Radioactive labelling of proteins in vitro. J. biol. Chem., 246, 831-832.

UTTER F. M., RIDGEWAY G. J., 1967. A serologically detected serum factor associated with maturity in english sole, Paraphyrys vefulus, and Pacific halibut, Hippoglossus stenolepis. Fish. Bull. U.S. Fish and Wildlife Serv., 66, 47-58.

WALLACE R. A., DUMONT J. N., 1968. The induced synthesis and transport of yolk proteins and their accumulation by the oocyte in Xenopus laevis. J. Cell Physiol,, 72 Suppl., 73-90.

WALLACE R. A., HO T., SALTER D. W., JARED D. W., 1973. Protein incorporation by isolated amphibian oocytes. IV. - The role of follicle cells and calcium ion during protein uptake. Exp. Cell Res., 82, 287-295.

WALLACE R. A., JARED D. W., 1976. Protein incorporation by isolated amphibian oocytes. V. Specificity for vitellogenin incorporation. J. Cell Biol., 69, 345-351.

WALLACE R. A., JARED D. W., NELSON B. L., 1970. Protein incorporation by isolated amphibian oocytes. 1. Preliminary studies. J. exp. Zool., 175, 259-270. 